Article

\title{
Characterization and Evaluation of Antioxidant and Anti-Inflammatory Activities of Flavonoids from the Fruits of Lycium barbarum
}

\author{
Tingting Yang ${ }^{1}$, Yuhang $\mathrm{Hu}^{1}{ }^{1}$, Yamei Yan ${ }^{2,3}$, Wangting Zhou ${ }^{1}$, Guijie Chen ${ }^{1} \mathbb{D}$, Xiaoxiong Zeng ${ }^{1, *}$ \\ and Youlong Cao ${ }^{2,3, *}$
}

check for updates

Citation: Yang, T.; Hu, Y.; Yan, Y.; Zhou, W.; Chen, G.; Zeng, X.; Cao, Y. Characterization and Evaluation of Antioxidant and Anti-Inflammatory Activities of Flavonoids from the Fruits of Lycium barbarum. Foods 2022, 11, 306. https://doi.org/10.3390/ foods11030306

Academic Editor: Arun K. Bhunia

Received: 8 December 202

Accepted: 19 January 2022

Published: 24 January 2022

Publisher's Note: MDPI stays neutral with regard to jurisdictional claims in published maps and institutional affiliations.

Copyright: (C) 2022 by the authors. Licensee MDPI, Basel, Switzerland. This article is an open access article distributed under the terms and conditions of the Creative Commons Attribution (CC BY) license (https:// creativecommons.org/licenses/by/ $4.0 /)$.
1 College of Food Science and Technology, Nanjing Agricultural University, Nanjing 210095, China; 2016208016@njau.edu.cn (T.Y.); 2019108064@njau.edu.cn (Y.H.); 2019208019@njau.edu.cn (W.Z.); guijiechen@njau.edu.cn (G.C.)

2 Institute of Wolfberry Engineering Technology, Ningxia Academy of Agriculture and Forestry Sciences, Yinchuan 750002, China; yanyamei@163.com

3 National Wolfberry Engineering Research Center, Yinchuan 750002, China

* Correspondence: zengxx@njau.edu.cn (X.Z.); youlongck@126.com (Y.C.); Tel.: +86-25-8439-6791 (X.Z.); +86-951-688-6783 (Y.C.); Fax: +86-25-8439-6791 (X.Z.)

\begin{abstract}
The fruits of Lycium barbarum are rich in flavonoids, which may contribute to the healthpromoting function of Lycium barbarum. However, the composition of flavonoids in the fruits of Lycium barbarum (LBFs) has received little attention. Thus, the goal of this work was to identify more kinds of flavonoids from fruits of Lycium barbarum by liquid chromatography-mass spectrometry. The potential antioxidant and anti-inflammatory activities of LBFs in vitro were also investigated. Thirteen flavonoid compounds were identified in LBFs, of which daphnetin, 6,7-dihydroxycoumarin, astragalin, taxifolin, eriodictyol, naringenin, and chrysoeriol were identified for the first time in the fruits of Lycium barbarum, which greatly enriched the variety of flavonoids in the fruits of Lycium barbarum. LBFs showed a similar superior antioxidant activity to vitamin C. Furthermore, LBFs exhibited an antiinflammatory activity by suppressing the production of nitric oxide and pro-inflammatory cytokines, including tumor necrosis factor-alpha, interleukin- $\beta$, and interleukin- 6 , in lipopolysaccharidetreated RAW264.7 macrophage cells. This study demonstrated the potential development of LBFs as functional foods.
\end{abstract}

Keywords: Lycium barbarum; flavonoids; liquid chromatography mass spectrometer (LC-MS); antioxidant; anti-inflammatory

\section{Introduction}

Flavonoids are a large group of polyhydroxyphenols and widely exist in food-borne plants, such as vegetables, fruits, and grains [1]. Flavonoids occupy the first place in natural phenols and are important secondary metabolites produced in the long-term evolution of plants [2]. These compounds have a variety of pharmacological activities such as antioxidant, antiviral, antitumor, antibacterial, and hypolipidemic activities [3-6]. In recent years, the concept of promoting human health by the intervening diet has attracted increasingly more attention from researchers [7]. At the same time, natural products have become a research hotspot in topics related to human nutrition and health due to their advantages of small side effects, no drug resistance, and high safety index [8]. However, it is difficult to separate and identify the flavonoids in plant-derived foods, which blocks their further practical applications in functional foods. Thus, the development of a strategy for the identification of flavonoids in different food materials is highly needed.

Lycium barbarum is one of the most important traditional Chinese medicines and edible plant species, which is also known as the Goji berry and Chinese wolfberry [9]. The 
active components of Lycium barbarum mainly include polyphenols, pigments, polysaccharides, flavonoids, amino acids, vitamins, and trace elements [10]. Among them, polyphenols, pigments, polysaccharides, and flavonoids are the quantitatively dominant substances in Lycium barbarum. In light of the reported research, the main polyphenols from Lycium barbarum are gallic acid, catechin, and chlorogenic acid [11]. Carotenoids are a class of natural fat-soluble pigments that exist in Lycium barbarum. According to the previous report [12], zeaxanthin dipalmitate is the main constituent of carotenoids in fully ripe fruits of Lycium barbarum. The most researched substances in the fruits of Lycium barbarum are polysaccharides [13]. In addition, rutin, quercetin, and kaempferol have been reported as the main flavonoids in Lycium barbarum [11]. The flavonoids from the fruits of Lycium barbarum (LBFs) have gradually become a research hotspot due to their prominent antioxidant, hypolipidemic, hypoglycemic, anti-tumor, and immunityenhancing activities and their prevention of cardiovascular and cerebrovascular diseases [1] At present, the research on LBFs mainly focuses on the optimization of extraction, separation, and purification. However, few studies have been performed on the identification and analysis of specific components of LBFs. Recently, a new method for the purification of flavonoids from Lycium barbarum with the mixed-mode macroporous adsorption resins (MARs) has been established by computer-assisted calculation of the molecular size of flavonoids and the precise matching of MAR physical and chemical properties [14]. In another study, five flavonoids and three isoflavones were identified in Lycium barbarum by HPLC combined with standards [15]. The purpose of the present study, therefore, was to identify more kinds of flavonoids from fruits of Lycium barbarum. First, the LBFs were extracted and purified by a resin column in this work. Then, the main flavonoids in LBFs were analyzed by liquid chromatography-mass spectrometry (LC-MS), aiming to provide potential insights into the flavonoids' composition in Lycium barbarum. Furthermore, the potential antioxidant and anti-inflammatory activities in vitro of LBFs were evaluated.

\section{Materials and Methods}

\subsection{Materials and Reagents}

The fresh fruits of Lycium barbarum (variety, Ningqi No. 1) were picked in July 2019 from the Wolfberry garden of the National Wolfberry Engineering Research Center (Yinchuan, China; $38^{\circ} 20^{\prime}$ north latitude and $106^{\circ} 16^{\prime}$ east longitude, altitude $2640 \mathrm{~m}$ ) and dried by gradient hot air at $45-55^{\circ} \mathrm{C}$, affording the dried fruits of Lycium barbarum.

The Cell Bank of the Chinese Academy of Sciences (Shanghai, China) provided the murine macrophage RAW264.7 cell line. High-glucose Dulbecco's modified Eagle's medium (DMEM), fetal bovine serum (FBS), and penicillin-streptomycin stock solution were purchased from Gibco (Carlsbad, CA, USA). Lipopolysaccharide (LPS) from Escherichia coli O111:B4 and 3-(4,5-dimethylthiazol-2-yl)-2,5-diphenyltetrazolium bromide (MTT) were obtained from Sigma-Aldrich Chemical Co., Ltd. (St. Louis, MO, USA). 1,1-Diphenyl-2-picrylhydrazyl (DPPH), reduced nicotinamide adenine dinucleotide (NADH), nitro-tetrazolium blue (NBT) chloride, and phenazine methosulphate (PMS) were purchased from Roche Ltd. (Basel, Switzerland). 2,2'-Azinobis-di-(3-ethyl-benzothiazolin6-sulfonic acid) diammonium salt (ABTS) and 2,4,6-tris(2-pyridyl)-striazine (TPTZ) were purchased from Aladdin Industrial Inc. (Shanghai, China). ELISA kits for the determination of tumor necrosis factor-alpha (TNF- $\alpha$ ), interleukin-6 (IL)-6, and interleukin-1 $\beta$ (IL-1 $\beta$ ) were purchased from Neobioscience Biological Technology Co., Ltd. (Shenzhen, China). The kit for the determination of nitric oxide (NO) free radicals was purchased from Beyotime Biotechnology Co., Ltd. (Shanghai, China). All other analytical reagents used in this study were obtained from Sinopharm Chemical Reagent Co., Ltd. (Shanghai, China).

\subsection{Extraction and Purification of LBFs}

The extraction of LBFs was carried out according to the previous report with slight modifications [16]. First, the dried Lycium barbarum fruits were ground into 80 mesh powder 
by a household food mincer (type, JYL-C020E) and extracted with $80 \%$ aqueous ethanol solution at $60{ }^{\circ} \mathrm{C}$ in triplicate. The extract was concentrated, mixed with $95 \%$ aqueous ethanol solution to precipitate the carbohydrates, and centrifuged. The supernatant was then loaded onto an AB-8 macroporous resin column and eluted with $80 \%$ aqueous ethanol solution, and the eluent was concentrated and lyophilized to afford LBFs.

In addition, the contents of main components in LBFs were detected by chemical coloration methods, which were the aluminum nitrate-sodium nitrite-sodium hydroxide colorimetric method [17] for the determination of flavonoids, phenol-sulfuric acid method [18] for the determination of total sugars, Coomassie dye binding method [19] for the determination of protein, and Folin-Ciocalteu assay [20] for the determination of total polyphenols.

\subsection{LC-MS Analysis of LBFs}

The extract of LBFs $(5.0 \mathrm{mg}$ ) was dissolved in $3.0 \mathrm{~mL}$ of water containing $0.1 \%$ formic acid (FA) and $2 \%$ acetonitrile (ACN) for LC-MS analysis [21]. An ACQUITY UPLC HSS T3 column $(2.1 \mathrm{~mm} \times 100 \mathrm{~mm}, 1.8 \mu \mathrm{m})$ and a guard column from Waters (Dublin, Ireland) were used. The column oven and auto-sampler temperature were maintained at $40{ }^{\circ} \mathrm{C}$ and $10{ }^{\circ} \mathrm{C}$, respectively. Mobile phase A was water containing $0.1 \% \mathrm{FA}(\mathrm{v} / \mathrm{v})$, and mobile phase $B$ was ACN. The following linear gradient was used: 0-1.0 $\mathrm{min}(2 \% \mathrm{~B}), 1.0-6.0 \mathrm{~min}$ (2-42\% B), 6.0-8.0 min (42-65\% B), 8.0-10.0 min (65-76\% B), 10.0-11.0 min (76-100\% B), and $11.0-14.0 \mathrm{~min}(100-100 \% \mathrm{~B})$. The flow rate was $0.40 \mathrm{~mL} / \mathrm{min}$, and the injector volume of the sample was $5 \mu \mathrm{L}$.

For MS analysis, Agilent 1290 II UPLC was coupled with AB Sciex QTOF 5600 Plus (AB Sciex Company, Concord, ON, Canada) and an electrospray ionization (ESI) source under negative ion mode [22]. The MS parameters used for detection were as follows: ESI source voltage, $4.5-5.5 \mathrm{kV}$; vaporizer temperature, $550{ }^{\circ} \mathrm{C}$; drying gas $\left(\mathrm{N}_{2}\right)$ pressure, $60 \mathrm{psi}$; atomizer gas $\left(\mathrm{N}_{2}\right)$ pressure, $60 \mathrm{psi}$; curtain gas $\left(\mathrm{N}_{2}\right)$ pressure, $35 \mathrm{psi}$; and depolymerization potential, $80 \mathrm{~V}$. The collision energy was $35 \pm 15 \mathrm{eV}$. The scanning range was $\mathrm{m} / \mathrm{z}$ 100-1000. Data acquisition and processing were carried out by using Analyst TF 1.7.1 software. The MS/MS analysis of flavonoids was carried out by the IDA method in information-dependent collection mode [23].

\subsection{Assay of Antioxidant Capacity}

\subsubsection{Assay for Scavenging Activity against DPPH Free Radicals}

The DPPH free radical scavenging activity was determined by the reported method with slight modifications [15]. Briefly, $25 \mu \mathrm{L}$ of $0.4 \mathrm{mM}$ DPPH radical solution in ethanol and $100 \mu \mathrm{L}$ of water were added to $50 \mu \mathrm{L}$ LBFs or vitamin $\mathrm{C}\left(\mathrm{V}_{\mathrm{C}}\right)$ solution at different concentrations $(25-800 \mu \mathrm{g} / \mathrm{mL})$. The reaction system was evenly mixed and reacted in the dark at $30^{\circ} \mathrm{C}$ for $30 \mathrm{~min}$. The absorbance (Abs) was measured at $517 \mathrm{~nm}$ using a Synergy HT microplate reader (Bio-Tek Instruments Inc., Burleigh, Winooski, VT, USA). All the samples were analyzed in three copies. The DPPH free radical scavenging rate was calculated by the following formula:

$$
\text { DPPH free radical scavenging rate }(\%)=\frac{\mathrm{Ab} s_{0}-\left(\mathrm{Ab} s_{1}-\mathrm{Ab} s_{2}\right)}{\mathrm{Ab} s_{0}} \times 100
$$

$A b s_{1}$ and $A b s_{0}$ are the Abs of the incubated DPPH free radical solution with and without the test substance, respectively; $\mathrm{Abs}_{2}$ is the $\mathrm{Abs}$ of the sample interference experiment (absolute ethanol instead of DPPH solution).

\subsubsection{Assay of Scavenging Activity on Hydroxyl Radicals}

The scavenging activity of LBFs on hydroxyl radicals was determined by the method of the report [24] with slight modifications. Briefly, $50 \mu \mathrm{L}$ of phenanthroline solution $(0.75 \mathrm{mM})$ and $75 \mu \mathrm{L}$ of phosphate buffer $(\mathrm{pH} 7.4,0.15 \mathrm{M})$ were fully mixed, and then $50 \mu \mathrm{L}$ of $\mathrm{FeSO}_{4}$ solution $(0.75 \mathrm{mM})$ was joined and mixed immediately. Subsequently, 
the LBF samples with different concentrations $(25-800 \mu \mathrm{g} / \mathrm{mL})$ or $\mathrm{V}_{\mathrm{C}}$ solutions were added to the reaction system and mixed well. Finally, $50 \mu \mathrm{L}$ of $0.01 \% \mathrm{H}_{2} \mathrm{O}_{2}$ solution was added to start the reaction. It should be noted that every reagent added to the system should be shaken up immediately; otherwise, the local color will be too deep to affect the repeatability of the experiment. Afterward, the reaction was carried out in a water bath at $37^{\circ} \mathrm{C}$ for $30 \mathrm{~min}$, and the Abs at $536 \mathrm{~nm}$ was determined by a spectrophotometer. The deionized water containing $0.1 \% \mathrm{H}_{2} \mathrm{O}_{2}$ was used as a negative control, and PBS was used as a blank control. The scavenging rate on hydroxyl radicals was calculated as follows:

$$
\text { Scavenging rate on hydroxyl radical }(\%)=\frac{\mathrm{Ab} s_{2}-\mathrm{A} 1}{\mathrm{Ab} s_{0}-\mathrm{Ab} s_{1}} \times 100
$$

$\mathrm{Abs}_{0}, \mathrm{Abs}_{1}$, and $\mathrm{Abs}_{2}$ are the Abs values of the blank control, negative control, and sample group, respectively.

\subsubsection{Assay of Scavenging Activity on Superoxide Anion Radicals}

The determination of scavenging activity on superoxide anion radicals was based on the method reported in the literature [25] with slight modifications. NADH, NBT, and PMS were diluted with PBS $(0.1 \mathrm{mM}, \mathrm{pH} 7.4)$, and $50 \mu \mathrm{L}$ of LBFs or $\mathrm{V}_{\mathrm{C}}$ solution $(25-800 \mu \mathrm{g} / \mathrm{mL})$, $50 \mu \mathrm{L}$ of NADH $(468 \mu \mathrm{M}), 50 \mu \mathrm{L}$ of NBT $(156 \mu \mathrm{M})$, and $50 \mu \mathrm{L}$ of PMS $(60 \mu \mathrm{M})$ were mixed in the 96 -well plate and maintained at $25{ }^{\circ} \mathrm{C}$ for $10 \mathrm{~min}$, and then the Abs at $560 \mathrm{~nm}$ was determined. The scavenging rate on superoxide anion radicals was calculated according to the following formula:

Scavenging rate on superoxide anion radicals $(\%)=\frac{\mathrm{Ab} s_{0}-\left(\mathrm{Ab} s_{1}-\mathrm{Abs} s_{2}\right)}{\mathrm{Ab} s_{0}} \times 100$

where $\mathrm{Abs}_{0}$ is the $\mathrm{Abs}$ of the control (deionized water instead of sample solution), $\mathrm{Abs}{ }_{1}$ is the $\mathrm{Abs}$ of the sample, and $\mathrm{Abs}_{2}$ is the $\mathrm{Abs}$ of the sample under the same conditions as $\mathrm{Abs}_{1}$ with PBS instead of NBT solution.

\subsubsection{Assay for Scavenging Activity on ABTS Radicals}

The scavenging activity on ABTS radicals was determined by the ABTS radical cation decolorization method [26]. In a nutshell, the ABTS solution (7.0 mM) was mixed with potassium persulfate $(4.95 \mathrm{mM})$ in equal proportion and stored in a dark place at room temperature for $12 \mathrm{~h}$. The ABTS radical solution was diluted with PBS (0.2 mM, pH 7.4) to a suitable $\mathrm{Abs}(0.70 \pm 0.02)$ at $734 \mathrm{~nm}$ and used as the working solution. Afterward, $20 \mu \mathrm{L}$ of LBFs or $\mathrm{V}_{C}$ with different concentrations was mixed with $200 \mu \mathrm{L}$ of working solution in a dark place. The Abs of the reaction system was measured at $734 \mathrm{~nm}$. The ABTS free radical scavenging activity was calculated as follows:

$$
\text { ABTS free radical scavenging activity }(\%)=\frac{1-\left(\mathrm{Ab} s_{1}-\mathrm{Ab} s_{2}\right)}{\mathrm{Ab} s_{0}} \times 100
$$

$\mathrm{Abs}_{0}$ is the Abs of the control with water instead of the sample, Abs 1 is the Abs of the sample, and $\mathrm{Abs}_{2}$ is the Abs of the sample with only PBS instead of ABTS.

\subsubsection{Assay of Total Antioxidant Capacity}

After mixing the sample or $\mathrm{V}_{\mathrm{C}}$ solution of different concentrations with PBS (0.2 M, $\mathrm{pH}$ 6.6) and potassium ferricyanide solution $(1 \%, \mathrm{~m} / \mathrm{v})$ in the same volume of $50 \mu \mathrm{L}$, the mixture was incubated at $50{ }^{\circ} \mathrm{C}$ for $20 \mathrm{~min}$. After reaction, the mixture was cooled quickly with running water, and trichloroacetic acid and ferric chloride solutions $(50 \mu \mathrm{L}$ each) were added in turn. The Abs of the mixture was measured at $700 \mathrm{~nm}$ [27]. The antioxidant capacity (Ac) was calculated as follows:

$$
\mathrm{Ac}=\mathrm{Abs}_{1}-\mathrm{Abs}_{2}
$$


where $\mathrm{Abs}_{1}$ is the Abs of the sample, and $\mathrm{Abs} s_{2}$ is the Abs of the control with water instead of ferric chloride solution.

\subsubsection{Assay for Ferric Reducing Antioxidant Potential (FRAP)}

The FRAP was determined according to the reported method [28] with some modifications. FRAP reagent was prepared by mixing $0.3 \mathrm{M}$ acetate buffer ( $\mathrm{pH} 3.6$ ), $10 \mathrm{mM}$ TPTZ, and ferric chloride with the appropriate proportion $(10: 1: 1, v / v / v)$. The FRAP reagent $(200 \mu \mathrm{L})$ was mixed with $20 \mu \mathrm{L}$ of sample solution and the reaction system was incubated at $25{ }^{\circ} \mathrm{C}$ for $10 \mathrm{~min}$. The Abs at $593 \mathrm{~nm}$ was then measured.

\subsection{Assay of Anti-Inflammatory Activity}

\subsubsection{Cell Culture and Assay of Cell Viability}

The cell culture and assay of cell viability were conducted according to the reported method [29]. In order to analyze the cytotoxicity of LBFs, cell viability was determined by an MTT assay. The cells were cultured in 96-well plates at a density of $5 \times 10^{4}$ cells per well for $12 \mathrm{~h}$, treated with different concentrations of LBFs $(10,20,50,100,150,200,300,400$, and $500 \mu \mathrm{g} / \mathrm{mL}$ ) for $2 \mathrm{~h}$, and then co-cultured with LPS (final concentration of $1 \mu \mathrm{g} / \mathrm{mL}$ ) for $24 \mathrm{~h}$ in a $5 \% \mathrm{CO}_{2}$ incubator at $37{ }^{\circ} \mathrm{C}$. Finally, the $\mathrm{Abs}$ at $570 \mathrm{~nm}$ was detected by an ELISA microplate reader (BioTeK Instruments, Inc., Winooski, VT, USA). The cell survival rate was calculated as follows:

$$
\text { Cell survival rate }(\%)=\frac{\mathrm{Abs} s_{570} \text { of treated cells }}{\mathrm{Ab} s_{570} \text { of untreated cells }} \times 100
$$

\subsubsection{Assay of NO Free Radicals}

The nitrite concentration in the medium was measured by the Griess method as the index of NO production [3]. Briefly, the RAW264.7 cells $\left(5 \times 10^{4} /\right.$ well $)$ were incubated in a 96-well plate for $24 \mathrm{~h}$ and treated with $1 \mu \mathrm{g} / \mathrm{mL}$ of LPS after pretreatment with different concentrations of LBFs for $2 \mathrm{~h}$. After co-culture in a $5 \% \mathrm{CO}_{2}$ incubator at $37{ }^{\circ} \mathrm{C}, 50 \mu \mathrm{L}$ of cell culture medium was collected and mixed with $50 \mu \mathrm{L}$ of Griess reagent I and II. The mixture was incubated at room temperature for $10 \mathrm{~min}$ with horizontal shaking, and the Abs of solution was measured at $540 \mathrm{~nm}$ by a microplate reader.

\subsubsection{Determination of Inflammatory Cytokines}

According to the manufacturer's instructions, the levels of proinflammatory cytokines (TNF- $\alpha$, IL-1 $\beta$, and IL-6) in the cell culture medium were measured [30]. In short, the RAW264.7 cells $\left(5 \times 10^{5} /\right.$ well $)$ were pretreated with $10-400 \mu \mathrm{g} / \mathrm{mL}$ of LBFs for $2 \mathrm{~h}$ before treatment with $1 \mu \mathrm{g} / \mathrm{mL}$ of LPS. After $24 \mathrm{~h}$ of culture, the incubation medium of each well was centrifuged $(2000 \times g)$ at $4^{\circ} \mathrm{C}$ for $10 \mathrm{~min}$, and the supernatant was taken to determine the levels of TNF- $\alpha$, IL-1 $\beta$, and IL- 6 . Their levels in the solution were calculated according to the standard curves of cytokines. All the experiments were carried out in triplicate.

\subsubsection{RNA Extraction and qRT-PCR Analysis}

According to the previously reported method, the mRNA expression levels of TNF- $\alpha$, IL-1 $\beta$, and IL-6 in macrophages were measured by qRT-PCR [29]. The RAW264.7 cells $\left(5 \times 10^{5}\right.$ /well) were inoculated into 6-well plates, after overnight culture; the cells were pretreated with different concentrations of LBFs for $2 \mathrm{~h}$; and they were then treated with $1 \mu \mathrm{g} / \mathrm{mL}$ of LPS for $16 \mathrm{~h}$. The total RNA was extracted from the cells by using the MiniBEST Universal RNA Extraction Kit (TaKaRa Co., Ltd., Beijing, China) according to the manufacturer's instructions. The concentration and purity of RNA samples were determined by a Nano Drop 2000 spectrophotometer (Thermo Fisher Scientific, Waltham, MA, USA), and the absorbance ratio of all the samples at $260 / 280 \mathrm{~nm}$ was in the range of 1.8-2.0. The qRT-PCR was completed with the Quant Studio ${ }^{\mathrm{TM}} 6$ Flex Real-Time PCR System (ABI, Carlsbad, CA, USA) on utilizing the Power $\mathrm{Up}^{\mathrm{TM}} \mathrm{SYBR}^{\circledR}$ Green Master Mix (ABI, Carlsbad, CA, USA). 
The procedure of qRT-PCR amplification was as follows: first, DNA polymerase was activated at $50{ }^{\circ} \mathrm{C}$ for $2 \mathrm{~min}$ and $95^{\circ} \mathrm{C}$ for $2 \mathrm{~min}$, and then the target DNA fragment was amplified for 40 cycles (denaturation at $95^{\circ} \mathrm{C}$ for $15 \mathrm{~s}$, annealing at $60{ }^{\circ} \mathrm{C}$, and renaturation with extension for $60 \mathrm{~s}$ ). Glyceraldehyde-3-phosphate dehydrogenase (GAPDH) was used as an internal reference, and all primer sequences are shown in Table 1.

Table 1. Sequences of PCR primers used for qRT-PCR.

\begin{tabular}{ccc}
\hline Target Gene & \multicolumn{1}{c}{ Primer Sequence } & Annealing T $\left({ }^{\circ} \mathbf{C}\right)$ \\
\hline TNF- $\alpha$ & $\begin{array}{c}\text { FW: CTCATGCACCACCATCAAGG } \\
\text { RV: ACCTGACCACTCTCCCTTTG }\end{array}$ & 60 \\
\hline IL-1 $\beta$ & $\begin{array}{c}\text { FW: AGCTTCAAATCTCGCAGCAG } \\
\text { RV: TCTCCACAGCCACAATGAGT }\end{array}$ & 59 \\
\hline \multirow{2}{*}{ IL-6 } & $\begin{array}{c}\text { FW: CTCTGGCGGAGCTATTGAGA } \\
\text { RV: AAGTCTCCTGCGTGGAGAAA }\end{array}$ & 60 \\
\hline \multirow{2}{*}{ GAPDH } & $\begin{array}{c}\text { FW: GGACTTACAGAGGTCCGCTT } \\
\text { RV: CTATAGGGCCTGGGTCAGTG }\end{array}$ & 59 \\
\hline
\end{tabular}

\subsection{Statistical Analysis}

All the experimental data are shown as means \pm standard deviation (S.D.) on three independent occasions. To estimate the statistical comparison of data, one-way analysis of variance (ANOVA) or Duncan's multiple-range test was used based on SPSS 22.0 software, considering $p<0.05$ to be statistically significant. It is worth noting that the $\mathrm{EC}_{50}$ (concentration required to obtain a $50 \%$ antioxidant effect) values in the antioxidant assays were also calculated by SPSS 22.0 software with the linear regression equation. All the graphics were made by Origin Pro 2021 SR0 software.

\section{Results and Discussion}

As shown in Figure 1, the contents of flavonoids, total carbohydrates, polyphenols, and proteins in LBFs were $80.09 \pm 0.60 \%, 4.09 \pm 0.63 \%, 11.04 \pm 1.25 \%$, and $4.78 \pm 0.82 \%$, respectively.

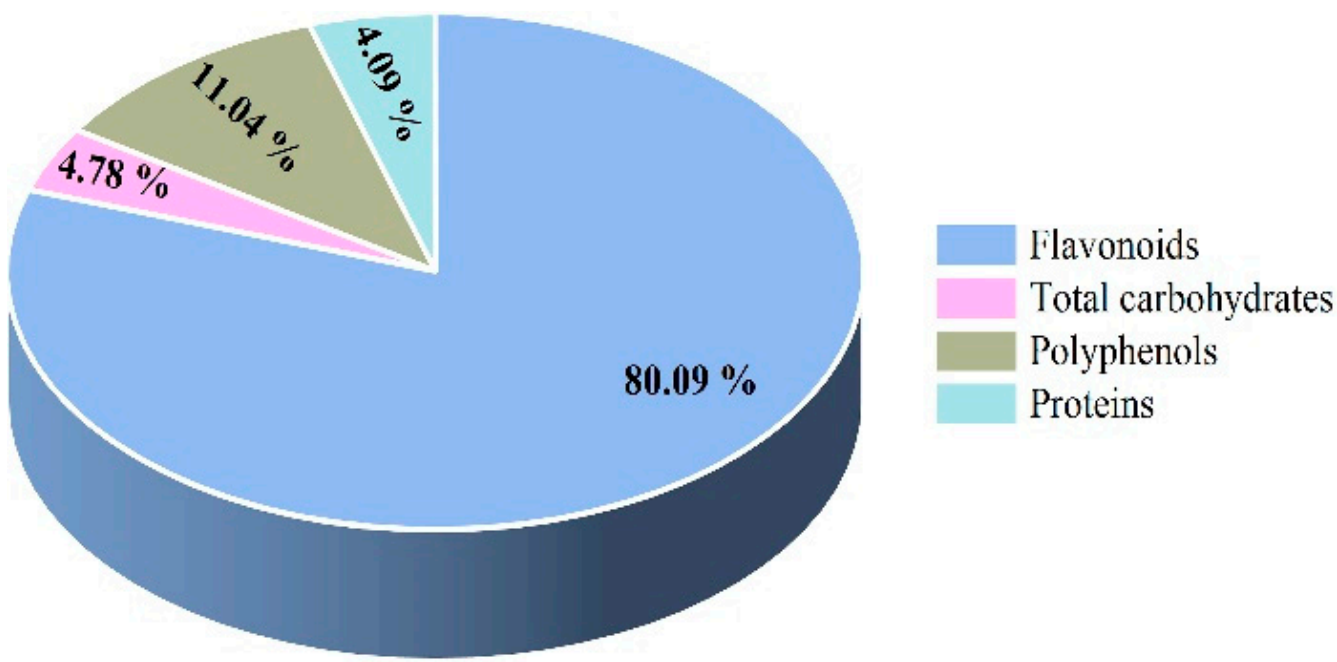

Figure 1. The category and percentage of main components in the extract of flavonoids from the fruits of Lycium barbarum.

\subsection{Identification of Flavonoids by $L C-M S$}

Flavonoids are identified as the main phytochemical compounds in Lycium barbarum. However, it is difficult to separate and identify the flavonoids in Lycium barbarum due to their abundant varieties. In the previous study, ultra-high-performance liquid chromatography with UV detection (UHPLC-UV) was used to analyze the flavonoids in the fruits 
of Lycium barbarum, and five kinds of flavonoids, including $( \pm)$-catechin, ( - -epicatechin, rutin, quercitrin, and hesperidin, were identified [1]. Likewise, Zhao et al. [31] identified four flavonoids including kaempferol, quercetin, isorhamnetin, and isoquercetin using matrix-assisted laser desorption/ionization mass spectrometry imaging (MALDI-MSI). However, these methods may omit some kinds of flavonoids. Thus, LC-MS was used to further identify the composition of flavonoids in Lycium barbarum in the present study, and the results are shown in Figure 2. Based on the previous reports [32-34], sixteen compounds were identified, including neochlorogenic acid (1), protocatechuic acid (2), 4-O-caffeoylquinic acid (3), daphnetin (4), 6,7-dihydroxycoumarin (5), rutin (6), hyperoside (7), kaempferol-3-O-rutinosid (8), astragalin (9), taxifolin (10), scopoletin (11), eriodictyol (12), quercetin (13), naringenin (14), chrysoeriol (15), and isorhamnetin (16) (Table 2). Of these, 6-8, 11, 13, and 16 are typical representatives of flavonoids in Lycium barbarum, which have been reported before [34,35]. In addition, 4, 5, 9, 10, 12, 14, and 15 were identified for the first time as the flavonoids in Lycium barbarum. 9, a characteristic natural flavone from Astragalus membranaceus, has strong antioxidant and anti-inflammatory activities [36]. 10, also known as dihydroquercetin [37], is a flavonoid extracted from the roots of Alpine Larix. It can effectively remove free radicals and toxins in the human body, which is regarded as a precious raw material for the production of food, medicine, and healthcare products. The other compounds such as 1-3 are classified into phenolic acids [14,32]. Among these substances, $\mathbf{1}$ is a natural polyphenolic compound usually found in dried fruits and other plants, and it can inhibit the production of TNF- $\alpha$ and IL-1 $\beta$, the expression of inducible NO synthase and cyclooxygenase-2, and the activation of phosphorylated NF- $\mathrm{BB}$ p65 and p38 MAPK [30]. 2 is a natural polyphenol with neuroprotective effects. Thus, the identified flavonoids in this work greatly enriched the variety of flavonoids in the fruits of Lycium barbarum.

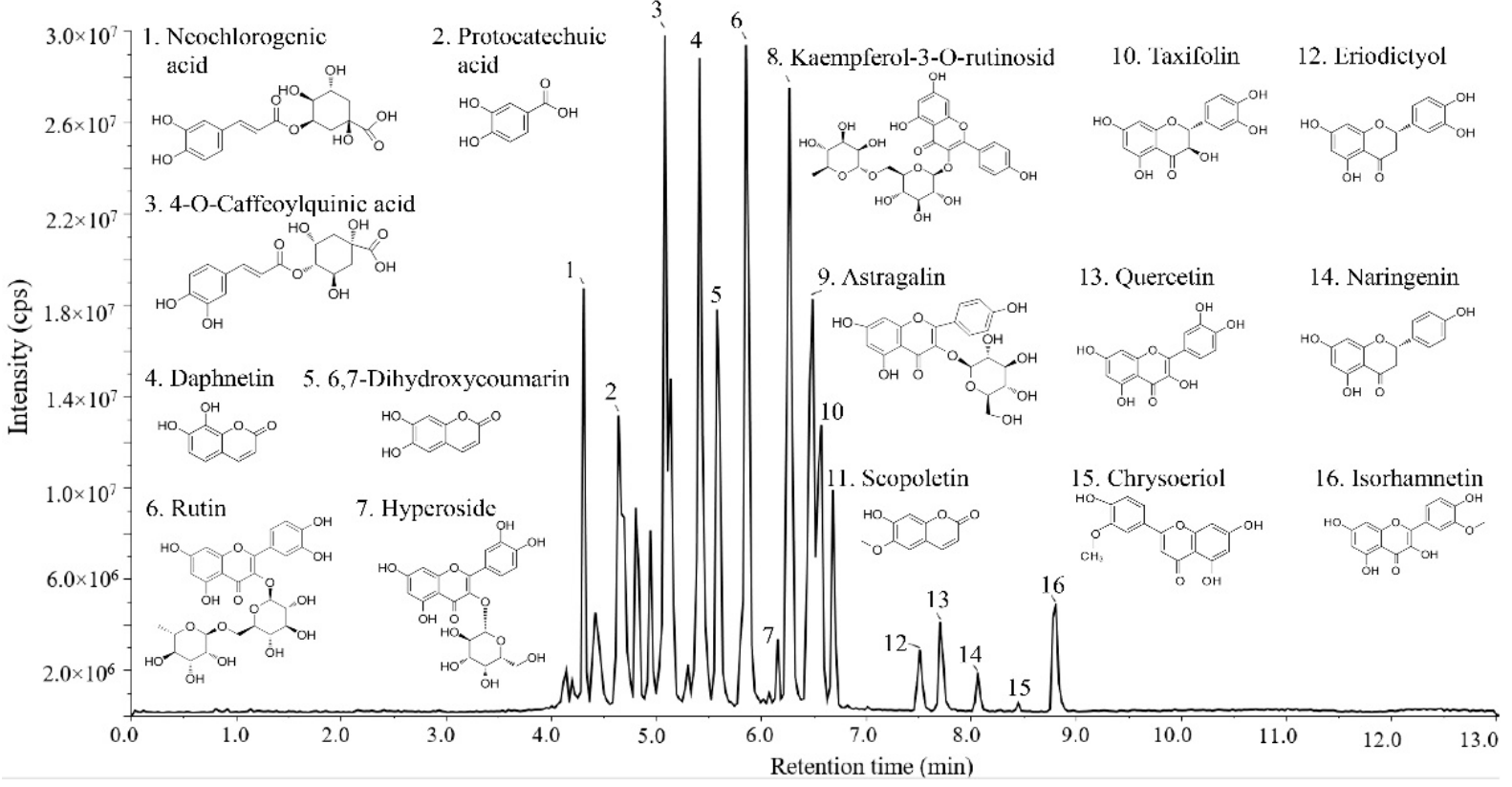

Figure 2. Total ion current chromatogram of sample solution by LC-MS. The names and molecular formulas of 16 compounds identified in the extract of flavonoids from the fruits of Lycium barbarum. 
Table 2. Identification of flavonoids in the fruits of Lycium barbarum.

\begin{tabular}{|c|c|c|c|c|}
\hline No. & Molecular Formula & Theoretical $m / z[\mathbf{M}-\mathbf{H}]$ & Retention Time & Component Name \\
\hline 1 & $\mathrm{C}_{16} \mathrm{H}_{18} \mathrm{O}_{9}$ & 353.309 & 4.31 & Neochlorogenic acid \\
\hline 2 & $\mathrm{C}_{7} \mathrm{H}_{6} \mathrm{O}_{4}$ & 153.120 & 4.64 & Protocatechuic acid \\
\hline 3 & $\mathrm{C}_{16} \mathrm{H}_{18} \mathrm{O}_{9}$ & 353.309 & 5.08 & 4-O-Caffeoylquinic acid \\
\hline 4 & $\mathrm{C}_{9} \mathrm{H}_{6} \mathrm{O}_{4}$ & 177.140 & 5.40 & Daphnetin \\
\hline 5 & $\mathrm{C}_{9} \mathrm{H}_{6} \mathrm{O}_{4}$ & 177.141 & 5.58 & 6,7-Dihydroxycoumarin \\
\hline 6 & $\mathrm{C}_{27} \mathrm{H}_{30} \mathrm{O}_{16}$ & 609.518 & 5.86 & Rutin \\
\hline 7 & $\mathrm{C}_{21} \mathrm{H}_{20} \mathrm{O}_{12}$ & 463.376 & 6.16 & Hyperoside \\
\hline 8 & $\mathrm{C}_{27} \mathrm{H}_{30} \mathrm{O}_{15}$ & 593.518 & 6.26 & Kaempferol-3-o-rutinosid \\
\hline 9 & $\mathrm{C}_{21} \mathrm{H}_{20} \mathrm{O}_{11}$ & 447.377 & 6.51 & Astragalin \\
\hline 10 & $\mathrm{C}_{15} \mathrm{H}_{12} \mathrm{O}_{7}$ & 303.252 & 6.56 & Taxifolin \\
\hline 11 & $\mathrm{C}_{10} \mathrm{H}_{8} \mathrm{O}_{4}$ & 191.168 & 6.72 & Scopoletin \\
\hline 12 & $\mathrm{C}_{15} \mathrm{H}_{12} \mathrm{O}_{6}$ & 287.252 & 7.65 & Eriodictyol \\
\hline 13 & $\mathrm{C}_{15} \mathrm{H}_{10} \mathrm{O}_{7}$ & 301.236 & 7.72 & Quercetin \\
\hline 14 & $\mathrm{C}_{15} \mathrm{H}_{12} \mathrm{O}_{5}$ & 271.253 & 8.07 & Naringenin \\
\hline 15 & $\mathrm{C}_{16} \mathrm{H}_{12} \mathrm{O}_{6}$ & 299.263 & 8.36 & Chrysoeriol \\
\hline 16 & $\mathrm{C}_{16} \mathrm{H}_{12} \mathrm{O}_{7}$ & 315.262 & 8.79 & Isorhamnetin \\
\hline
\end{tabular}

\subsection{Antioxidant Activities of LBFs}

The antioxidant activities of LBFs were determined and the results are shown in Figure 3. Compared with $\mathrm{V}_{\mathrm{C}}$ (positive control), highly concentration-dependent manners of antioxidant activities were found for LBFs at low concentrations $(<400 \mu \mathrm{g} / \mathrm{mL})$. As shown in Figure 3A, when the concentration was over $400 \mu \mathrm{g} / \mathrm{mL}$, the scavenging rate of LBFs against DPPH radicals was similar to that of $\mathrm{V}_{C}(55.7 \pm 1.9 \%)$. In addition, the $\mathrm{EC}_{50}$ value was calculated to further quantify the scavenging rate of the sample (Table 3 ). It is generally believed that the lower the $\mathrm{EC}_{50}$ value is, the higher the scavenging ability is. Although the $\mathrm{EC}_{50}$ value of $\mathrm{V}_{\mathrm{C}}$ was much lower than that of LBFs, with the increase in concentration, the clearance rate of LBFs to DPPH free radicals increased significantly to the same level as $\mathrm{V}_{\mathrm{C}}$, indicating that LBFs showed a strong scavenging activity on DPPH free radicals.

Table 3. $E_{50}$ values of antioxidant activities of the extract of flavonoids from the fruits of Lycium barbarum (LBFs) and $\mathrm{V}_{\mathrm{C}}$ determined by DPPH free radical scavenging assay, hydroxyl radical (HR) scavenging assay, superoxide radical (SR) scavenging assay, and ABTS radical scavenging assay. Data are shown as the means \pm S.D. Data bearing different letters are significantly different $(p<0.05)$.

\begin{tabular}{ccc}
\hline & LBFs & VC \\
\hline $\mathrm{EC}_{50 / \mathrm{DPPH}}(\mathrm{mg} / \mathrm{mL})$ & $294.864 \pm 2.470^{\mathrm{b}}$ & $40.436 \pm 1.607^{\mathrm{a}}$ \\
$\mathrm{EC}_{50 / \mathrm{HR}}(\mathrm{mg} / \mathrm{mL})$ & $275.048 \pm 2.439^{\mathrm{a}}$ & $265.520 \pm 2.424^{\mathrm{a}}$ \\
$\mathrm{EC}_{50 / \mathrm{SR}}(\mathrm{mg} / \mathrm{mL})$ & $66.463 \pm 1.80^{\mathrm{b}}$ & $1.919^{\mathrm{b}} \pm 0.283^{\mathrm{a}}$ \\
$\mathrm{EC}_{50 / \mathrm{ABTS}}(\mathrm{mg} / \mathrm{mL})$ & $82.663 \pm 1.917^{\mathrm{b}}$ & $34.348 \pm 1.536^{\mathrm{a}}$ \\
\hline
\end{tabular}

The hydroxyl radical is one kind of important reactive oxygen species (ROS), which has strong oxidizability and is the only oxidant next to fluorine in nature [6]. As shown in Figure 3B, LBFs showed a similar scavenging activity for hydroxyl radicals with that of the positive control at the concentration range of $25-400 \mu \mathrm{g} / \mathrm{mL}$. When the LBF concentration was higher than $400 \mu \mathrm{g} / \mathrm{mL}$, the scavenging rate on hydroxyl radicals of LBFs showed a slow downward trend, which was slightly weaker than that of $\mathrm{V}_{\mathrm{C}}$. At the same time, there was no significant difference in the $\mathrm{EC}_{50}$ values between LBFs and $\mathrm{V}_{\mathrm{C}}$ (Table 3), which further confirmed the results. As shown in Figure 3C, LBFs exhibited a lower scavenging rate of superoxide radicals in the concentrations of 25-350 $\mu \mathrm{g} / \mathrm{mL}$ compared with $\mathrm{V}_{\mathrm{C}}$, whereas the scavenging capacity of LBFs was higher than that of $\mathrm{V}_{\mathrm{C}}(p<0.05)$, when the concentration of LBFs ranged from 400 to $700 \mu \mathrm{g} / \mathrm{mL}$. The same trend was also observed in the assay for scavenging activity on ABTS radicals (Figure 3D). When the sample concentration was higher than $300 \mu \mathrm{g} / \mathrm{mL}$, the scavenging rate of LBFs was 
almost equal to that of $\mathrm{V}_{\mathrm{C}}$, and there was no significant difference between the two groups $(p>0.05)$.
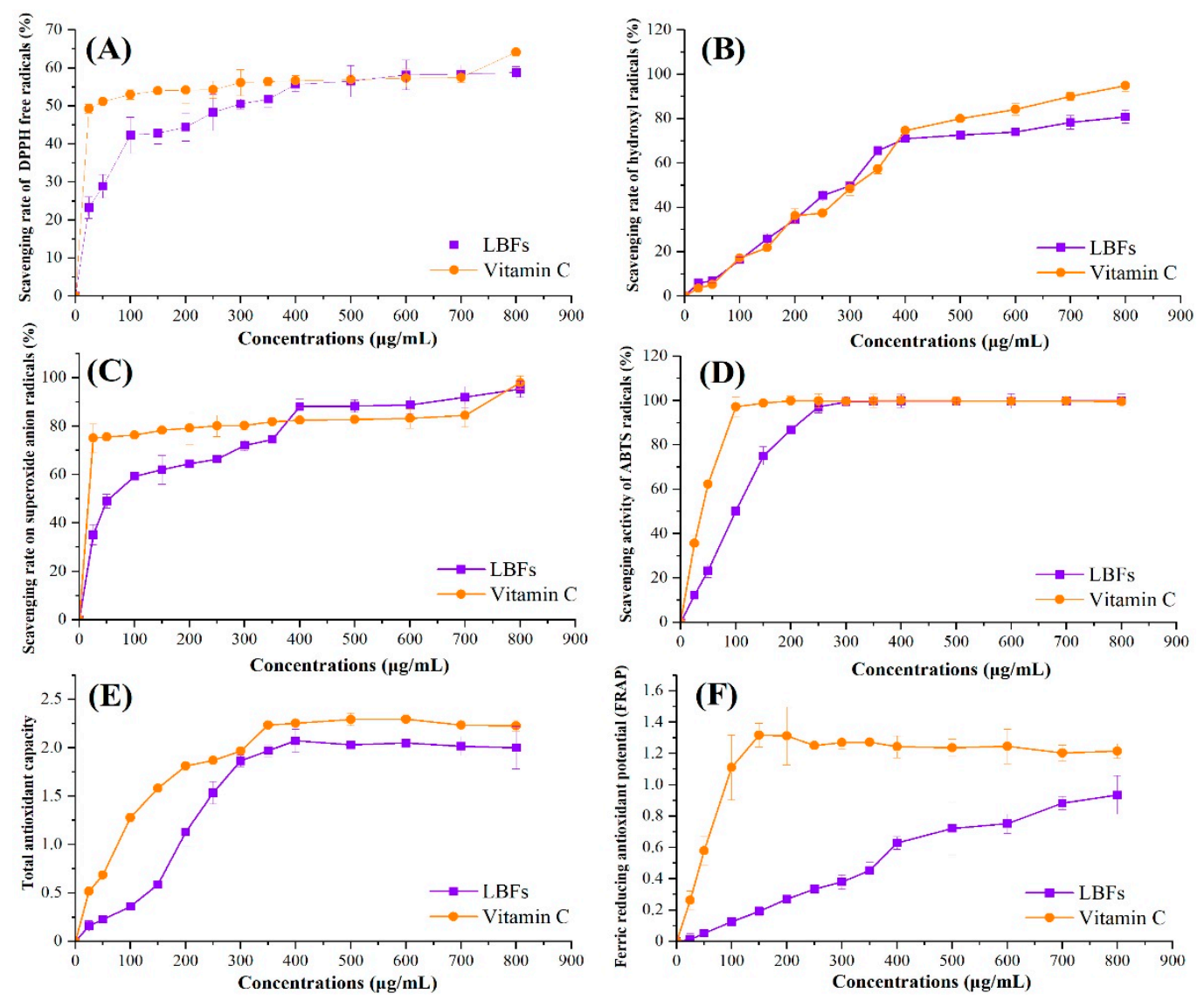

Figure 3. Comparison of antioxidant activities of the extract of flavonoids from the fruits of Lycium barbarum and $\mathrm{V}_{\mathrm{C}}$ determined by DPPH free radical-scavenging assay (A), hydroxyl radicalscavenging assay (B), superoxide radical-scavenging assay (C), ABTS radical-scavenging assay (D), total reducing capacity (TRC) assay (E), and FRAP assay (F). The concentrations of sample solution were $25,50,100,150,200,250,300,350,400,500,600,700$, and $800 \mu \mathrm{g} / \mathrm{mL}$ in the proper order. Each value was expressed as means \pm S.D. $(n=3)$.

Antioxidant activity is directly and positively correlated with reducing capacity [38]. Reducing capacity is usually related to the existence of reducing ketones, which exert an antioxidant effect by providing hydrogen atoms to break free radical chains. The electron-donating ability of a reducing agent is usually determined by the potassium ferricyanide reduction method [11]. Figure 3E shows the total reducing capacities of LBFs and $V_{C}$. The total reducing capacities of all samples increased tightly along with the increase in concentration. When the concentration was $400 \mu \mathrm{g} / \mathrm{mL}$, the total reducing capacities of LBFs and $\mathrm{V}_{\mathrm{C}}$ were $2.07 \pm 0.12$ and $2.25 \pm 0.03(p<0.05)$, respectively, and remained unchanged with the further increase in concentration.

FRAP is another method to measure the antioxidant activity of samples based on the blue-purple complex formed by ferrous ions and TPTZ under low-pH conditions [28]. As exihibited in Figure 3F, compared with the positive control, the FRAP value of LBFs was in a highly concentration-dependent manner. The FRAP values of LBFs and Vc were 0.63 \pm 0.04 and $1.24 \pm 0.07(p<0.05)$, respectively, when the concentration was $400 \mu \mathrm{g} / \mathrm{mL}$. Thereafter, as the concentration increased, the FRAP value of Vc gradually decreased, and the rising trend of the FRAP value of LBFs gradually slowed down. When the concentration reached $800 \mu \mathrm{g} / \mathrm{mL}$, the FRAP values of LBFs and Vc were $0.94 \pm 0.12$ and $1.22 \pm 0.05$, respectively. 
In conclusion, LBFs exhibited antioxidant activities, including superior scavenging activities on DPPH, hydroxyl, superoxide ABTS radicals, and a noticeable ferric reducing antioxidant. It has been reported that the components of $80 \%$ ethanol extracts were considered to have the greatest contribution to the antioxidant activity of Lycium barbarum [10]. Based on the previous work and results in this work, the main components of Lycium barbarum extracted with $80 \%$ aqueous ethanol solution were flavonoids, except a small amount of other polyphenols. It has also been pointed out in other research on the chromatographic determination and antioxidant activity evaluation of phenolic acids and flavonoids in Lycium barbarum that the flavonoid components such as rutin, quercetin, and naringenin showed a high effect on scavenging DPPH free radicals [1]. The studies of flavonoids in strawberry, blueberry, and chokeberry also showed similar antioxidant activities as Lycium barbarum flavonoids with reducing ability and radical scavenging activity $[39,40]$. In addition, the analysis of the antioxidant components and total antioxidant capacity of goji berries confirmed that the scavenging ability and the ability to prevent the formation of free radicals were closely related to the concentration and composition of flavonoids of Lycium barbarum [41]. Thus, it was speculated that flavonoids might be the important active components contributing to the antioxidant activity of Lycium barbarum.

\subsection{Anti-Inflammatory Activity of LBFs}

Epidemiological studies have shown that excessive production of proinflammatory factors may lead to the development of chronic inflammatory diseases, such as cancer, inflammatory bowel disease, and metabolic syndrome [42]. The mouse macrophage RAW264.7 cell line is generally considered as a suitable cell model for the in vitro study of anti-inflammatory diseases [43]. LPS is the main component of the cell wall of Gramnegative bacteria, which is widely used to establish the macrophage inflammation model in vitro [44]. In this study, the inflammatory model of RAW264.7 macrophages stimulated by LPS was used to investigate the anti-inflammatory activity of LBFs.

\subsubsection{Effects of LBFs on Cell Viability}

The safety evaluation should be carried out before the development of LBFs for functional foods. Thus, an MTT assay was used to evaluate the effect of LBFs on the viability of RAW264.7 macrophages [29]. In view of the concentration-dependent manner of LBFs in the antioxidant experiment, the cells were pretreated with $10-500 \mu \mathrm{g} / \mathrm{mL}$ of LBFs for $2 \mathrm{~h}$ and then treated with $1 \mu \mathrm{g} / \mathrm{mL}$ of LPS for $24 \mathrm{~h}$. As shown in Figure $4 \mathrm{~A}, \mathrm{LBFs}$ at the concentration of $10-400 \mu \mathrm{g} / \mathrm{mL}$ showed limited effect on cell viability with and without the addition of LPS. When the concentration of LBFs was at $500 \mu \mathrm{g} / \mathrm{mL}$, the cell viability was significantly reduced to $72.71 \pm 2.39 \%(p<0.05)$ compared with the blank control. Therefore, LBFs at the concentration of $10-400 \mu \mathrm{g} / \mathrm{mL}$ had no cytotoxicity on RAW264.7 cells, which was used for the subsequent experiments.

\subsubsection{Effects of LBFs on the Production of NO}

$\mathrm{NO}$, a short-lived free radical produced in a wide variety of cells, has various biological functions in response to inflammatory stimuli, such as LPS, which is regarded as an indicator of inflammatory response. To evaluate the effect of LBFs on the production of LPS-induced NO in RAW264.7 cells, the level of NO in the culture medium was detected by Griess assays. As shown in Figure 4B, the level of NO in macrophages was significantly increased by treatment with $1 \mu \mathrm{g} / \mathrm{mL}$ of LPS $(p<0.05)$ compared with the blank control. Nevertheless, pretreatment with LBFs could noticeably decrease the LPS-induced NO production in a dose-dependent manner. Especially, the production of NO decreased to $6.15 \pm 0.58 \mu \mathrm{M}$ after pretreatment with LBFs at $400 \mu \mathrm{g} / \mathrm{mL}$. These results indicated that LBFs exihibited anti-inflammatory activity by the inhibition of NO production in a remarkably concentration-dependent manner. 
(A)
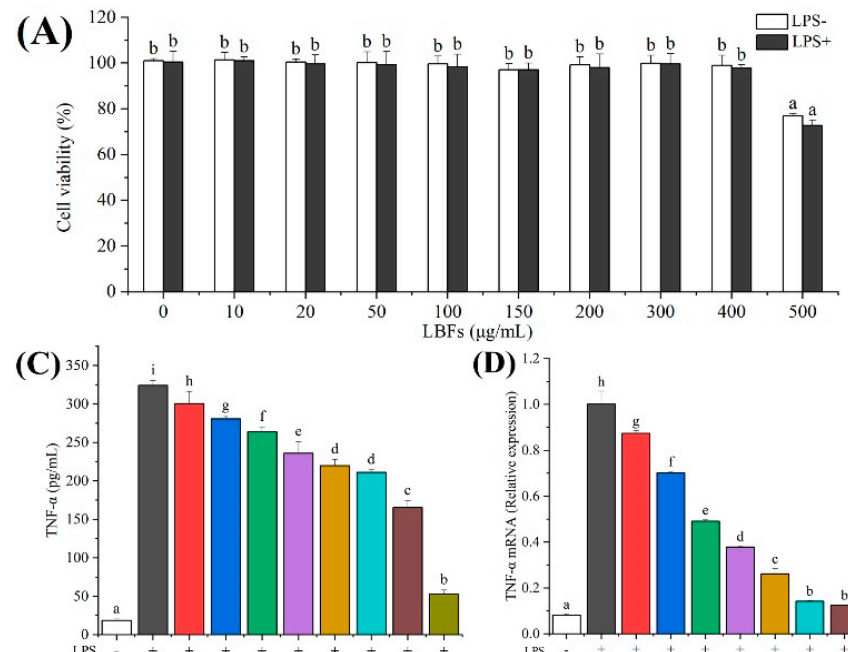

(F)

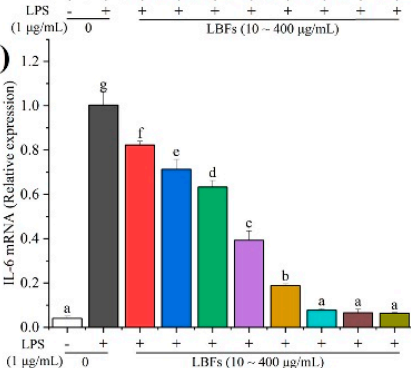

(D) ${ }^{1.2}$

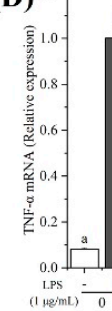

$(\mathbf{G})^{30}$

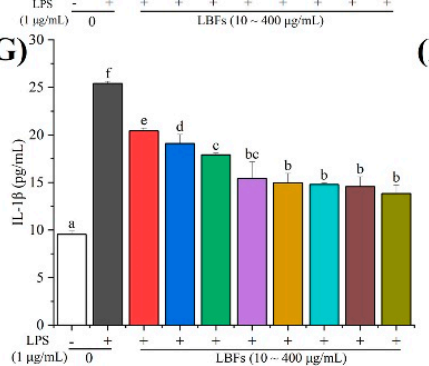

(B)

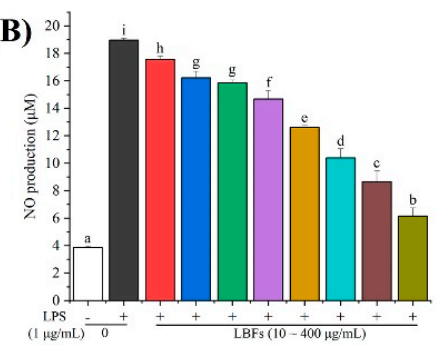

(E)

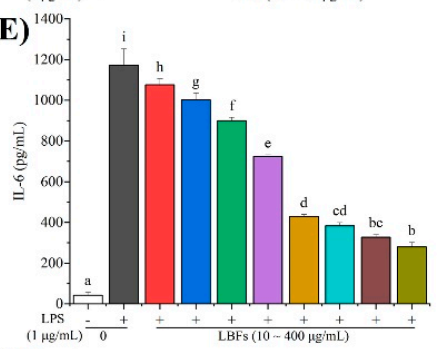

(H)

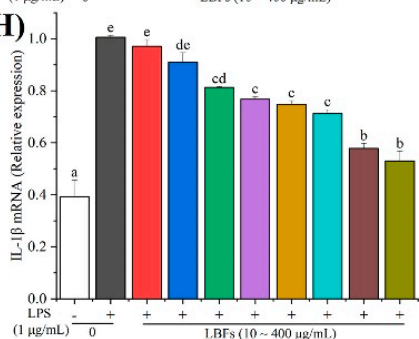

Figure 4. Cytotoxic effects on RAW264.7 cells and effects on LPS-induced pro-inflammatory cytokine production and mRNA expression of the extract of flavonoids from the fruits of Lycium barbarum. In cytotoxicity test (A), cells were pretreated with different concentrations (10, 20, 50, 100, 150, 200, 300, and $400 \mu \mathrm{g} / \mathrm{mL}$ ) of LBFs for $2 \mathrm{~h}$ and then treated with $1 \mu \mathrm{g} / \mathrm{mL}$ of LPS for $24 \mathrm{~h}$. (B) The NO level in the cell culture was detected by Griess assay. In the anti-inflammatory activity test, RAW264.7 cells were pretreated with different concentrations of LBFs for $2 \mathrm{~h}$ and then coexisted with LPS for $24 \mathrm{~h}$. The culture supernatant was collected, and the levels of TNF- $\alpha$ (C), IL-6 (E), and IL-1 $\beta$ (G) were detected by ELISA kits. At the same time, cellular lysate was added into the culture well to extract total mRNA, and then the mRNA expression levels of TNF- $\alpha(\mathbf{D})$, IL-6 (F), and IL-1 $\beta$ (H) were determined by qRT-PCR. Each value is shown as means \pm S.D. $(n=3)$. Data with diverse letters are significantly different $(p<0.05)$.

3.3.3. Effects of LBFs on the Production of LPS-Induced Pro-Inflammatory Cytokines and mRNA Expression

Macrophages are widely distributed in the human body and play a key role in the immune system by providing an immediate defense against foreign pathogens. LPS is one of the most powerful activators of macrophages, as we know [4]. The activation of macrophages by LPS is the result of toll-like receptor-4 (TLR-4)-mediated intracellular signaling cascades, and ultimately leads to the expression of proinflammatory mediators, such as TNF- $\alpha$, IL-6, and IL-1 $\beta$ [45]. TNF- $\alpha$ is the earliest and most important inflammatory mediator in the process of inflammatory reaction, which can activate neutrophils and lymphocytes, increase the permeability of vascular endothelial cells, regulate the metabolic activity of other tissues, and promote the synthesis and release of other cytokines [43]. Both IL- 6 and IL- $1 \beta$ belong to IL, which is a kind of cytokine of the chemokine family, and they can induce B-cells to differentiate and produce antibodies and T-cells to proliferate and differentiate. They participate in the immune response of the body and are the promoters of inflammatory reaction [44].

In the present study, the effects of LBFs on the LPS-induced production of TNF- $\alpha$, IL- 6 , and IL- $1 \beta$ were investigated by ELISA. The results indicated that the levels of TNF- $\alpha$, IL-6, and IL-1 $\beta$ remarkably increased from $18.54 \pm 1.86$ to $324.11 \pm 6.13 \mathrm{pg} / \mathrm{mL}$ (Figure 4C), $42.22 \pm 14.09$ to $1172.36 \pm 80.73 \mathrm{pg} / \mathrm{mL}$ (Figure $4 \mathrm{E}$ ), and $9.53 \pm 0.35$ to $25.41 \pm 0.23 \mathrm{pg} / \mathrm{mL}$ 
(Figure 4G), respectively, after a $24 \mathrm{~h}$ intervention with LPS alone compared with the blank control. In addition, the inhibitory effects of LBFs pretreatment on the LPS-induced production of TNF- $\alpha$, IL-6, and IL- $1 \beta$ were observed in a dose-dependent manner. Especially, when the pretreatment of LBFs was at $400 \mu \mathrm{g} / \mathrm{mL}$, the LPS-induced levels of TNF- $\alpha$, IL-6, and IL-1 $\beta$ declined to $52.62 \pm 5.46,280.13 \pm 21.79$, and $13.84 \pm 0.88 \mathrm{pg} / \mathrm{mL}$, respectively.

Furthermore, the mRNA expression levels of TNF- $\alpha$, IL-6, and IL-1 $\beta$ in RAW264.7 cells were investigated, and the results showed that the mRNA expression levels of TNF- $\alpha$, IL-6, and IL-1 $\beta$ significantly increased after LPS-stimulation in the RAW264.7 macrophage cells $(p<0.05)$, which is consistent with the previous work $[29,44]$. As expected, the mRNA expression levels of TNF- $\alpha$, IL-6, and IL-1 $\beta$ decreased by preconditioning with different concentrations $(10-400 \mu \mathrm{g} / \mathrm{mL})$ of LBFs (Figure 4D,F,H). Especially, the mRNA expression levels of TNF- $\alpha$, IL-6, and IL-1 $\beta$ decreased to $11.01 \pm 1.69 \%, 6.37 \pm 0.3 \%$, and $53.04 \pm 3.77 \%$ after treatment of LBFs at $400 \mu \mathrm{g} / \mathrm{mL}$, respectively, compared with those of the cells acitivated with LPS alone.

In the process of inflammation, high levels of IL- $1 \beta$ and IL- 6 can lead to fever, hypotension, immune disorder, and chronic inflammation, while overexpression of NO and TNF- $\alpha$ can promote T-cells to produce various inflammatory cytokines, including IL-1 $\beta$ and IL-6, and then stimulate the occurrence of an inflammatory response [3]. In this study, RAW264.7 cells were stimulated by LPS to produce excessive inflammatory mediators of NO and TNF- $\alpha$, and proinflammatory cytokines of IL- $1 \beta$ and IL- 6 . However, the levels of inflammatory mediators (NO and TNF- $\alpha$ ) and cytokines (IL-1 $\beta$ and IL-6) in RAW264.7 cells decreased significantly in a dose-dependent manner after intervention with LBFs. In conclusion, LBFs showed a good anti-inflammatory effect by inhibiting the excessive secretion of inflammatory mediators and inflammatory factors in the process of inflammation. These results suggested that the decrease in TNF- $\alpha$, IL- 6 , and IL-1 $\beta$ production in a concentration-dependent manner by LBFs might be related to the transcriptional inhibition of the genes of TNF- $\alpha$, IL- 6 , and IL- $1 \beta$.

Existing studies have shown that baicalein exerts its anti-inflammatory effect by inhibiting mitogen-induced T-cell activation, proliferation, and cytokine secretion [46]. Anti-oxidative assays as markers for the anti-inflammatory activity of flavonoids showed that with the increase in flavonoids (quercetin, hyperoside, eriodictyol, naringenin, isorhamnetin, etc.) at different concentrations $(10,20$, and $50 \mathrm{mg} / \mathrm{L})$, the gene expression levels of inflammatory factors such as IL-1 $\beta$, IL-6, IL-8, and TNF- $\alpha$ were remarkably decreased [47]. Moreover, the study of antioxidant and anti-inflammatory activities of 100 pure compounds pointed out that kaempferol and quercetin could effectively inhibit the secretion of IL-6, IL-1 $\beta$, and TNF- $\alpha$. Quercetin (10-25 mol/L) could reduce the contents of NO and TNF- $\alpha$ in mouse glioma cells induced by LPS [48]. In the study of the regulating pathway by astragalin to endotoxin-induced oxidative stress [36], astragalin inhibits endotoxin-induced oxidative stress by interfering with the TLR-4-PKC $\beta 2-N A D P H$ oxidase signal pathway, improving epithelial eosinophilia and apoptosis related to oxidative stress, and reducing the levels of inflammatory factors and their gene expression of inflammation. Thus, LBFs showed superior antioxidant and anti-inflammatory activities, which might be responsible for the health-promoting functions of Lycium barbarum. However, the antioxidant and antiinflammatory activities of flavonoids in vivo are still unknown, which should be further investigated by animal models. Furthermore, the specific component responsible for the bioactivities of flavonoids from Lycium barbarum is still unknown; thus, we should separate and purify each flavonoid in LBFs and evaluate the bioactivity in the future. This work demonstrated the potential bioactivity of flavonoids from Lycium barbarum in vitro, which may promote the further works on bioactivities in vivo of flavonoids from the fruits of Lycium barbarum. 


\section{Conclusions}

In the present study, thirteen flavonoids in LBFs were identified by LC-MS. Among them, seven kinds of flavonoids (daphnetin, 6,7-dihydroxycoumarin, astragalin, taxifolin, eriodictyol, naringenin, and chrysoeriol) were identified in Lycium barbarum for the first time. In the aspect of antioxidant activity, LBFs showed a strong free radical scavenging ability and reducing capacity in a dose-dependent manner. Moreover, LBFs pretreatment in the LPS-induced macrophages model could reduce the inflammatory response by inhibiting the production of inflammatory mediators and cytokines. The results suggested the potential antioxidant and anti-inflammatory activities of LBFs, providing the theoretical foundation and experimental evidence for the further applications of Lycium barbarum in food and pharmaceutical industries.

Author Contributions: Conceptualization, Data Curation, Investigation, Methodology, Writing—original draft, T.Y.; Investigation, Y.H.; Resource, Investigation, Y.Y.; Investigation, W.Z.; Investigation, G.C.; Conceptualization, Funding acquisition, Project administration, Supervision, Writing-review and editing, X.Z.; Funding acquisition, Y.C. All authors have read and agreed to the published version of the manuscript.

Funding: This research was funded by Priority Academic Program Development of Jiangsu Higher Education Institutions and the Key Research and Development Program of Ningxia Hui Autonomous Region of China (2021BEF02008 and 2019BFG02026).

Institutional Review Board Statement: Not applicable.

Informed Consent Statement: Not applicable.

Data Availability Statement: The data presented in this study are available in the article.

Conflicts of Interest: The authors declare that no known competing interests will influence the work reported in this paper.

\section{References}

1. Magiera, S.; Zaręba, M. Chromatographic determination of phenolic acids and flavonoids in Lycium barbarum L. and evaluation of antioxidant activity. Food Anal. Methods 2015, 8, 2665-2674. [CrossRef]

2. Cushnie, T.P.T.; Lamb, A.J. Recent advances in understanding the antibacterial properties of flavonoids. Int. J. Antimicrob. Agents 2011, 38, 99-107. [CrossRef]

3. Chen, G.; Fan, M.; Wu, J.; Li, N.; Guo, M. Antioxidant and anti-inflammatory properties of flavonoids from lotus plumule. Food Chem. 2019, 277, 706-712. [CrossRef] [PubMed]

4. Wu, M.; Wang, C.; Mai, C.; Chen, J.; Lai, X.; He, L.; Huang, S.; Zhang, X. Flavonoids from Livistona chinensis fruit ameliorates LPS/D-GalN-induced acute liver injury by inhibiting oxidative stress and inflammation. J. Funct. Foods 2019, 61, 103460. [CrossRef]

5. Baba, S.A.; Malik, S.A. Determination of total phenolic and flavonoid content, antimicrobial and antioxidant activity of a root extract of Arisaema jacquemontii Blume. J. Taibah Univ. Sci. 2015, 9, 449-454. [CrossRef]

6. Xie, J.; Dong, C.; Nie, S.; Li, F.; Wang, Z.; Shen, M.; Xie, M. Extraction, chemical composition and antioxidant activity of flavonoids from Cyclocarya paliurus (Batal.) Iljinskaja leaves. Food Chem. 2015, 186, 97-105. [CrossRef] [PubMed]

7. Evans, L.W.; Stratton, M.S.; Ferguson, B.S. Dietary natural products as epigenetic modifiers in aging-associated inflammation and disease. Nat. Prod. Rep. 2020, 37, 653-676. [CrossRef]

8. Bisson, J.; Simmler, C.; Graham, J.; McAlpine, J.B.; Friesen, B.J.; Lankin, D.C.; Chen, S.N.; Orjala, J.; Pauli, G.F. A new dedicated center to connect scientists and advance natural product research. Planta Med. 2016, 82, P1029. [CrossRef]

9. Gao, Y.; Wei, Y.; Wang, Y.; Gao, F.; Chen, Z. Lycium Barbarum: A traditional Chinese herb and a promising anti-aging agent. Aging Dis. 2017, 8, 778. [CrossRef]

10. Lu, Y.; Guo, S.; Zhang, F.; Yan, H.; Qian, D.; Wang, H.; Jin, L.; Duan, J. Comparison of functional components and antioxidant activity of Lycium barbarum L. fruits from different regions in China. Molecules 2019, 24, 2228. [CrossRef]

11. Mocan, A.; Cairone, F.; Locatelli, M.; Cacciagrano, F.; Carradori, S.; Vodnar, D.C.; Crișan, G.; Simonetti, G.; Cesa, S. Polyphenols from Lycium barbarum (Goji) fruit European cultivars at different maturation steps: Extraction, HPLC-DAD analyses, and biological evaluation. Antioxidants 2019, 8, 562. [CrossRef]

12. Kan, X.; Yan, Y.; Ran, L.; Lu, L.; Mi, J.; Zhang, Z.; Li, X.; Zeng, X.; Cao, Y. Ultrasonic-assisted extraction and high-speed counter-current chromatography purification of zeaxanthin dipalmitate from the fruits of Lycium barbarum L. Food Chem. 2020, 310, 125854. [CrossRef] 
13. Amagase, H.; Farnsworth, N.R. A review of botanical characteristics, phytochemistry, clinical relevance in efficacy and safety of Lycium barbarum fruit (Goji). Food Res. Int. 2011, 44, 1702-1717. [CrossRef]

14. Liu, J.; Meng, J.; Du, J.; Liu, X.; Pu, Q.; Di, D.; Chen, C. Preparative separation of flavonoids from Goji berries by mixed-mode macroporous adsorption resins and effect on A $\beta$-expressing and anti-aging genes. Molecules 2020, 25, 3511. [CrossRef]

15. Zhou, Z.; Xiao, J.; Fan, H.; Yu, Y.; He, R.; Feng, X.; Kurihara, H.; So, K.; Yao, X.; Gao, H. Polyphenols from wolfberry and their bioactivities. Food Chem. 2017, 214, 644-654. [CrossRef]

16. Wu, S.; Wang, Y.; Gong, G.; Li, F.; Ren, H.; Liu, Y. Adsorption and desorption properties of macroporous resins for flavonoids from the extract of Chinese wolfberry (Lycium barbarum L.). Food Bioprod. Processing 2015, 93, 148-155. [CrossRef]

17. Chen, S.; Li, X.; Liu, X.; Wang, N.; An, Q.; Ye, X.M.; Zhao, Z.T.; Zhao, M.; Han, Y.; Ouyang, K.H.; et al. Investigation of chemical composition, antioxidant activity, and the effects of Alfalfa flavonoids on growth performance. Oxid. Med. Cell. Longev. 2020, 2020, 8569237. [CrossRef]

18. DuBois, M.; Gilles, K.A.; Hamilton, J.K.; Rebers, P.A.; Smith, F. Colorimetric method for determination of sugars and related substances. Anal. Chem. 1956, 28, 350-356. [CrossRef]

19. Shareef, M.M.; Shetty, K.T. Effect of vanadate on different forms of Coomassie brilliant blue and protein assay. Anal. Biochem. 1998, 258, 143-146. [CrossRef]

20. Škerget, M.; Kotnik, P.; Hadolin, M.; Hraš, A.R.; Simonič, M.; Knez, Ž. Phenols, proanthocyanidins, flavones and flavonols in some plant materials and their antioxidant activities. Food Chem. 2005, 89, 191-198. [CrossRef]

21. Song, Y.; Fu, Y.; Huang, S.; Liao, L.; Wu, Q.; Wang, Y.; Ge, F.; Fang, B. Identification and antioxidant activity of bovine bone collagen-derived novel peptides prepared by recombinant collagenase from Bacillus cereus. Food Chem. 2021, 349, 129143. [CrossRef] [PubMed]

22. Tian, H.; Zhou, Z.; Shui, G.; Lam, S.M. Extensive profiling of polyphenols from two trollius species using a combination of untargeted and targeted approaches. Metabolites 2020, 10, 119. [CrossRef] [PubMed]

23. Moo-Huchin, V.M.; Moo-Huchin, M.I.; Estrada-León, R.J.; Cuevas-Glory, L.; Estrada-Mota, I.A.; Ortiz-Vázquez, E.; Betancur-Ancona, D.; Sauri-Duch, E. Antioxidant compounds, antioxidant activity and phenolic content in peel from three tropical fruits from Yucatan, Mexico. Food Chem. 2015, 166, 17-22. [CrossRef] [PubMed]

24. Zhou, R.; Li, S. In vitro antioxidant analysis and characterization of antler velvet extract. Food Chem. 2009, 114, 1321-1327. [CrossRef]

25. Xie, M.; Hu, B.; Wang, Y.; Zeng, X. Grafting of gallic acid onto Chitosan enhances antioxidant activities and alters rheological properties of the copolymer. J. Agric. Food Chem. 2014, 62, 9128-9136. [CrossRef]

26. Liu, L.; Sun, Y.; Laura, T.; Liang, X.; Ye, H.; Zeng, X. Determination of polyphenolic content and antioxidant activity of kudingcha made from Ilex kudingcha C.J. Tseng. Food Chem. 2009, 112, 35-41. [CrossRef]

27. Tang, J.; Yan, Y.; Ran, L.; Mi, J.; Sun, Y.; Lu, L.; Gao, Y.; Zeng, X.; Cao, Y. Isolation, antioxidant property and protective effect on PC12 cell of the main anthocyanin in fruit of Lycium ruthenicum Murray. J. Funct. Foods 2017, 30, 97-107. [CrossRef]

28. Fang, Z.; Zhang, Y.; Lü, Y.; Ma, G.; Chen, J.; Liu, D.; Ye, X. Phenolic compounds and antioxidant capacities of bayberry juices. Food Chem. 2009, 113, 884-888. [CrossRef]

29. Wan, P.; Xie, M.; Chen, G.; Dai, Z.; Hu, B.; Zeng, X.; Sun, Y. Anti-inflammatory effects of dicaffeoylquinic acids from Ilex kudingcha on lipopolysaccharide-treated RAW264.7 macrophages and potential mechanisms. Food Chem. Toxicol. 2019, 126, 332-342. [CrossRef]

30. Kim, M.; Choi, S.; Lee, P.; Hur, J. Neochlorogenic acid inhibits lipopolysaccharide-induced activation and pro-inflammatory responses in BV2 microglial cells. Neurochem. Res. 2015, 40, 1792-1798. [CrossRef]

31. Zhao, W.; Zhang, Y.; Shi, Y. Visualizing the spatial distribution of endogenous molecules in wolfberry fruit at different development stages by matrix-assisted laser desorption/ionization mass spectrometry imaging. Talanta 2021, 234, 122687. [CrossRef]

32. Ali, M.C.; Chen, J.; Zhang, H.; Li, Z.; Zhao, L.; Qiu, H. Effective extraction of flavonoids from Lycium barbarum L. fruits by deep eutectic solvents-based ultrasound-assisted extraction. Talanta 2019, 203, 16-22. [CrossRef]

33. Xie, C.; Li, Y.; Gao, J.; Wang, Y. Esculetin regulates the phenotype switching of airway smooth muscle cells. Phytother. Res. 2019, 33, 3008-3015. [CrossRef]

34. Zhang, Y.; Wang, B.; Jia, Z.; Scarlett, C.J.; Sheng, Z. Adsorption/desorption characteristics and enrichment of quercetin, luteolin and apigenin from Flos populi using macroporous resin. Rev. Bras. Farmacog. 2019, 29, 69-76. [CrossRef]

35. Cid-Ortega, S.; Monroy-Rivera, J.A. Extraction of kaempferol and its glycosides using supercritical fluids from plant sources: A review. Food Technol. Biotechnol. 2018, 56, 480-493. [CrossRef]

36. Cho, I.; Gong, J.; Kang, M.; Lee, E.; Park, J.H.Y.; Park, S.; Kang, Y. Astragalin inhibits airway eotaxin-1 induction and epithelial apoptosis through modulating oxidative stress-responsive MAPK signaling. BMC Pulm. Med. 2014, 14, 122. [CrossRef]

37. Angelis, A.; Hubert, J.; Aligiannis, N.; Michalea, R.; Abedini, A.; Nuzillard, J.; Gangloff, S.; Skaltsounis, A.; Renault, J. Bioguided isolation of methanol-soluble metabolites of common spruce (Picea abies) bark by products and investigation of their dermo-cosmetic properties. Molecules 2016, 21, 1586. [CrossRef]

38. Jiang, C.; Xiong, Q.; Gan, D.; Jiao, Y.; Liu, J.; Ma, L.; Zeng, X. Antioxidant activity and potential hepatoprotective effect of polysaccharides from Cyclina sinensis. Carbohyd. Polym. 2013, 91, 262-268. [CrossRef]

39. Hwang, S.J.; Yoon, W.B.; Lee, O.; Cha, S.J.; Kim, J.D. Radical-scavenging-linked antioxidant activities of extracts from black chokeberry and blueberry cultivated in Korea. Food Chem. 2014, 146, 71-77. [CrossRef] 
40. Żebrowska, J.; Dyduch-Siemińska, M.; Gawroński, J.; Jackowska, I.; Pabich, M. Genetic estimates of antioxidant properties in the conventionally and in vitro propagated strawberry (Fragaria $\times$ ananassa Duch). Food Chem. 2019, 299, 125110. [CrossRef]

41. Protti, M.; Gualandi, I.; Mandrioli, R.; Zappoli, S.; Tonelli, D.; Mercolini, L. Analytical profiling of selected antioxidants and total antioxidant capacity of goji (Lycium spp.) berries. J. Pharmaceut. Biomed. 2017, 143, 252-260. [CrossRef]

42. Fehér, J.; Kovács, I.; Balacco Gabrieli, C. Role of gastrointestinal inflammations in the development and treatment of depression. Orv. Hetil. 2011, 152, 1477-1485. [CrossRef]

43. Lee, W.; Shin, J.; Jang, D.S.; Lee, K. Cnidilide, an alkyl phthalide isolated from the roots of Cnidium officinale, suppresses LPS-induced NO, PGE 2 , IL-1 $\beta$, IL-6 and TNF- $\alpha$ production by AP-1 and NF- $\mathrm{BB}$ inactivation in RAW264.7 macrophages. Int. Immunopharmacol. 2016, 40, 146-155. [CrossRef]

44. Shi, Q.; Cao, J.; Fang, L.; Zhao, H.; Liu, Z.; Ran, J.; Zheng, X.; Li, X.; Zhou, Y.; Ge, D.; et al. Geniposide suppresses LPS-induced nitric oxide, $\mathrm{PGE}_{2}$ and inflammatory cytokine by downregulating NF- $\mathrm{KB}, \mathrm{MAPK}$ and $\mathrm{AP}-1$ signaling pathways in macrophages. Int. Immunopharmacol. 2014, 20, 298-306. [CrossRef]

45. Damlar, I.; Esen, E.; Tatli, U. Effects of glucosamine-chondroitin combination on synovial fluid IL-1 $\beta$, IL-6, TNF- $\alpha$ and PGE 2 levels in internal derangements of temporomandibular joint. Med. Oral Patol. Oral Cir. Bucal 2015, 20, e278-e283. [CrossRef]

46. Patwardhan, R.S.; Sharma, D.; Thoh, M.; Checker, R.; Sandur, S.K. Baicalein exhibits anti-inflammatory effects via inhibition of NF- $\mathrm{kB}$ transactivation. Biochem. Pharmacol. 2016, 108, 75-89. [CrossRef]

47. Chanput, W.; Krueyos, N.; Ritthiruangdej, P. Anti-oxidative assays as markers for anti-inflammatory activity of flavonoids. Int. Immunopharmacol. 2016, 40, 170-175. [CrossRef]

48. Lee, K.J.; Oh, Y.C.; Cho, W.K.; Ma, J.Y. Antioxidant and anti-inflammatory activity determination of one hundred kinds of pure chemical compounds using offline and online screening HPLC assay. Evid.-Based Complement. Altern. 2015, 2015, 165457. [CrossRef] 